\title{
Analisis Tegangan Akibat Beban Gelombang pada Struktur Kapal Perang Tipe Corvette
}

\author{
Pratama Yuli Arianto, Aries Sulisetyono, Teguh Putranto \\ Jurusan Teknik Perkapalan, Fakultas Teknologi Kelautan, Institut Teknologi Sepuluh Nopember (ITS) \\ Jl. Arief Rahman Hakim, Surabaya 60111 Indonesia \\ e-mail: sulisea@na.its.ac.id, theories@na.its.ac.id
}

\begin{abstract}
Abstrak-Peningkatan sektor pertahanan nasional merupakan suatu hal yang penting dalam mempertahankan kedaulatan suatu negara. Salah satu diantaranya adalah dengan membuat Alat Utama Sistem Pertahanan Negara (ALUTSISTA) berupa kapal perang yang memiliki kecepatan tinggi, maneuver dan kekuatan struktur yang bagus. Ketika terjadi interaksi antara struktur kapal dengan beban gelombang maka akan muncul suatu tegangan. Jika tegangan yang dihasilkan melebihi batas tegangan yang diijinkan maka akan membahayakan dan merusak struktur kapal. Penelitian ini bertujuan untuk mengkaji desain lambung dan kekuatan struktur kapal untuk daerah operasional di perairan terbuka Indonesia yang memiliki tinggi rata-rata gelombang 3-5 m dan menurut standar Germanischer Lloyd (GL) dengan tinggi rata-rata gelombang $6 \mathrm{~m}$. Pembahasan dititikberatkan pada analisis gerakan kapal untuk mengetahui kekuatan struktur kapal akibat adanya beban gelombang. Analisis dilakukan dengan melakukan pemodelan numerik dengan metode panel. Skenario divariasikan berdasarkan sudut hadap $90^{\circ}, 135^{\circ}, 180^{\circ}$ dan tinggi gelombang signifikan $3,4,5$ dan $6 \mathrm{~m}$. Dari hasil simulasi didapatkan besar gaya lintang maksimal pada gerakan heaving dan momen lengkung maksimal pada gerakan pitching yang terjadi pada midship section ketika tinggi gelombang $6 \mathrm{~m}$ dan sudut hadap $180^{\circ}$. Tegangan terbesar kapal terjadi ketika kondisi sagging dan hogging maksimal yang terletak pada midship section frame 88 sebesar $231,89 \mathrm{~N} / \mathrm{mm}^{2}$ dan memenuhi persyaratan tegangan izin berdasarkan $G L$ rules.
\end{abstract}

Kata kunci-beban gelombang, struktur kapal, sudut hadap, tegangan, tinggi gelombang

\section{PENDAHULUAN}

I NDONESIA merupakan negara maritim, dimana memiliki wilayah laut yang luas serta didukung dengan banyaknya pulau-pulau di dalamnya. Dengan jumlah pulau sekitar $\pm 17,5$ ribu pulau dan luas wilayah laut Indonesia mencapai $\pm 5,8$ juta $\mathrm{km}^{2}$. Dengan didukung kondisi geografisnya sudah seharusnya Indonesia mampu menjadi negara yang berdaulat. Berdaulat terhadap keamanan wilayah dan kekayaan sumberdaya lautnya dengan meningkatkan aspek-aspek yang mendukung terciptanya negara berdaulat adil dan makmur yang salah satunya yaitu aspek pertahanan militer.

Pertahanan militer merupakan suatu kekuatan utama pertahanan negara yang dibangun dan dipersiapkan untuk menjaga kedaulatan negara serta menghadapi ancaman militer. Peningkatan sektor pertahanan militer nasional merupakan suatu hal yang penting dalam mempertahankan keutuhan suatu negara. Karena kita tahu akhir-akhir ini telah terjadi banyak pelanggaran-pelanggaran di wilayah laut Indonesia oleh negara lain, seperti kasus pencurian ikan secara ilegal (ilegal fishing), penyelundupan barang, penyelundupan narkoba, penyelundupan manusia (human trafficking), terorisme dan bajak laut. Dimana hal ini dapat terjadi karena lemahnya pengamanan laut di Indonesia. Dalam bidang maritim salah satu cara meningkatakan pertahanan nasional adalah dengan meningkatkan sektor Alat Utama Sistim Pertahanan Negara (ALUTSISTA) berupa kapal perang yang mumpuni baik dari segi kecepatan, maneuver, stabilitas, dan didukung persenjataan yang memadai.

Dalam mendesain suatu kapal perang yang mumpuni, dalam hal teknis juga harus mempertimbangkan kekuatan konstruksi dari kapal tersebut. Baik kekuatan secara memanjang, maupun melintang, dan juga kekuatan puntir dari kapal tersebut. Selain itu juga mempertimbangkan faktor alam yang berupa gelombang air laut yang dikenal dengan beban gelombang. Beban gelombang adalah beban yang ditimbulkan karena interaksi antara permukaan badan kapal dengan gelombang air laut. Dimana mengakibatkan kapal melakukan gerakangerakan mulai dari surging, heaving, swaying, rolling, pitching, dan yawing, sehingga dapat mempengaruhi struktur kapal. Ketika struktur kapal mendapatkan beban gelombang secara berulang-ulang atau yang disebut dengan beban siklik (cyclic load), maka akan mempengaruhi tegangan pada struktur kapal tersebut. Jika tegangan yang dihasilkan melebihi batas tegangan yang diijinkan maka akan membahayakan dan akan merusak struktur kapal tersebut.

Kapal perang corvette merupakan jenis kapal perang yang lebih kecil dari fregat dan lebih besar dari kapal patroli. Kapal perang corvette ini masuk dalam jenis kapal perang kombatan atau kapal penyerang. Dimana memiliki kekuatan struktur kapal yang lebih besar apabila dibandingkan dengan kapal komersil pada umumnya [1].

Dalam hal menganalisis struktur kapal tidak terlepas dari adanya tegangan yang terjadi akibat beban gelombang dengan ketinggian yang berbeda-beda. Digunakannya kapal yang masih dalam tahap desain untuk mengantisipasi terjadinya kerusakan pada struktur kapal. Germanischer Lloyd (GL Class) memiliki standar gelombang dengan tinggi $6 \mathrm{~m}$ dan menurut Badan Meteorologi Klimatologi dan Geofisika (BMKG) tinggi gelombang ekstrim rata-rata di Indonesia adalah 3-5 $\mathrm{m}$ [2]. 
Perumusan masalah yang dibahas pada penelitian ini adalah (i) bagaimana menentukan bending moment dan shear force yang terjadi pada kapal perang tipe corvette, (ii) berapa besar tegangan pada struktur kapal akibat beban gelombang dengan tinggi gelombang $6 \mathrm{~m}$ (standar GL rules), (iii) berapa besar tegangan pada struktur kapal akibat beban gelombang dengan tinggi gelombang 3-5 m (kondisi perairan Indonesia), (iv) bagaimana analisis besar tegangan yang dihasilkan dengan tegangan yang diizikan oleh klasifikasi.

\section{DASAR TEORI}

\section{A. Teori Gelombang}

Dalam studi olah gerak kapal (seakeeping) perlu dipelajari terlebih dahulu mengenai gelombang. Gelombang didefinisikan sebagai perubahan bentuk akibat gerakan permukaan air. Setiap gelombang yang dimaksudkan pada penelitian ini adalah gelombang air laut. Sebelum mempelajari lebih jauh mengenai gelombang, lebih dahulu diperkenalkan hal-hal yang berhubungan dengan gelombang sebagai berikut:

1) Puncak gelombang (crest) adalah titik dimana permukaan air berada pada elevasi tertinggi.

2) Jumlah halaman artikel adalah 3-6.Lembah gelombang (trough) adalah titik dimana permukaan air berada pada elevasi terendah.

3) Garis datum adalah garis datar permukaan air (diambil secara statistik) pada waktu air tenang.

4) Elevasi gelombang ( $(\zeta)$ adalah jarak suatu titik pada permukaan gelombang dengan garis datum pada suatu waktu tertentu.

5) Amplitudo gelombang $(\zeta w)$ adalah garis vertikal antara titik tertinggi atau titik terendah dengan garis datum.

6) Panjang gelombang $(\lambda)$ adalah jarak dari puncak (lembah) gelombang dengan puncak (lembah) gelombang berikutnya.

7) Kecepatan gelombang (v) adalah jarak yang ditempuh suatu titik per satuan waktu.

8) Frekuensi gelombang $(\omega)$ adalah banyaknya puncak (lembah) gelombang yang dilalui oleh suatu titik per satuan waktu [3].

\section{B. Gerak pada Kapal}

Pada dasarnya kapal mengalami 2 jenis gerakan yaitu gerakan translasi dan rotasi. Karena kapal merupakan benda 3 dimensi dimana setiap jenis gerakan bergerak terhadap 3 sumbu yaitu sumbu $\mathrm{x}, \mathrm{y}$ dan $\mathrm{z}$.

Gerakan translasi yang dialami kapal antara lain gerakan vertikal naik turun searah sumbu z (heave), gerakan ke kiri dan ke kanan searah sumbu y (sway) dan gerakan ke arah depan dan belakang searah sumbu x (surge). Gerakan rotasi yang dialami kapal antara lain rotasi terhadap sumbu $\mathrm{x}(\mathrm{roll})$, rotasi terhadap sumbu y (pitch), dan rotasi terhadap sumbu z (yaw). Jadi, berdasarkan uraian tersebut kapal mengalami 6 macam gerakan saat mendapat gaya dari gelombang saat berada di air laut maupun air tawar.
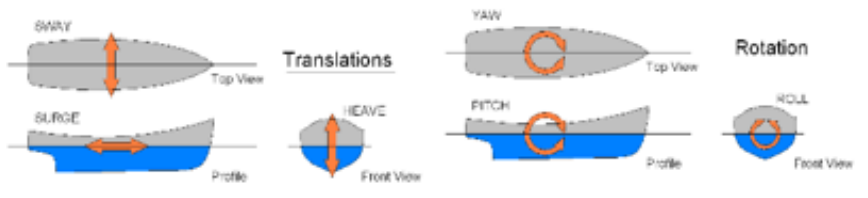

Gambar. 1. Visualisasi gerakan kapal

Setiap gerakan memiliki sebuah persamaan umum yang didalamnya terdapat beberapa komponen,

$a \ddot{z}+b \dot{z}+c z=F_{0} \cos \omega_{e} t$

Persamaan diatas menggambarkan gerakan heaving dan disebut sebagai forced heaving motion. Untuk gerakan translasi lainnya, persamaan tersebut dapat diterapkan dengan mengubah sumbu axis gerakan terhadap sumbu $\mathrm{x}$ dan $\mathrm{y}$, dimana a adalah virtual mass (massa kapal ditambah dengan added mass), $\mathrm{b}$ adalah koefisien damping(gaya melawan arah gerakan), c adalah koefisien restorting force (gaya pengembali ke titik setimbang) dan Fo adalah exsisting force / encountering force atau gaya luar yang bekerja pada kapal. Jika kapal berada pada kondisi air tenang (calm water) maka Fo adalah nol [3].

\section{Response Amplitude Operators (RAO)}

Response Amplitude Operator (RAO) atau sering disebut sebagai transfer function adalah fungsi response yang terjadi akibat gelombang dalam rentang frekuensi yang mengenai struktur offshore. RAO disebut sebagai Transfer Function karena RAO merupakan alat untuk mentransfer beban luar (gelombang) dalam bentuk response pada suatu struktur. Persamaan RAO dapat dicari dengan rumus sebagai berikut [3]:

$R A O=X p(\omega) / \eta(\omega)$

dimana,

$X p(\omega) \quad=$ amplitudo struktur

$\eta(\omega) \quad=$ amplitudo gelombang

\section{Spektrum Gelombang (Spektrum ITTC/ISSC - 1975)}

Pada acara International Towing Tank Conference (ITTC) ke-14 pada tahun 1975 di kota Ottawa, Canada, Mirokhin dan Kholodilin telah mengajukan suatu formula baru untuk spektra gelombang, dengan mempertimbangkan perkembangan data mutakhir pada saat itu. Para peserta yang terdiri dari pakar hidrodinamika dari berbagai laboratorium hidrodinamika sedunia yang tergabung dalam ITTC kemudian menyetujui formulasi tersebut untuk dijadikan standar utama dalam berbagai pengujian perilaku gerakan kapal di gelombang acak, dengan bentuk sebagai berikut [4]:

$S_{\zeta}(\omega)=\frac{0.0081 \cdot \mathrm{g}^{2}}{\omega^{5}} \times \exp \left(\frac{-3.11}{H_{S}^{2} \cdot \omega^{4}}\right)$

dimana,

$$
\begin{aligned}
S_{\zeta}(\omega) & =\text { Spektrum Gelombang } \\
\mathrm{g} & =\text { gravitasi }
\end{aligned}
$$




$$
\begin{array}{cl}
\omega & =\text { frekuensi } \\
\mathrm{Hs} & =\text { tinggi gelombang signifikan }
\end{array}
$$

\section{E. Beban Gelombang}

Beban Gelombang (Wave load) merupakan suatu beban dari suatu gelombang, baik air laut, angin, maupun yang lainnya. Dimana penerapannya paling umum diterapkan pada suatu benda atau struktur. Hal ini paling sering digunakan dalam analisis pipa, kapal, atau struktur bangunan yang terkena angin, air, maupun gangguan seismik.

Pada saat kapal beroperasi pada kondisi normal di laut, maka akan mengalami beban gelombang yang mempengaruhi kekuatan memanjang kapal, kondisi inilah sering kita sebut dengan hogging dan sagging. Untuk itu diperlukan perhitungan bending moment kapal yang dipengaruhi oleh [3] Vertical Bending moment, akibat defleksi sumbu-Y, Horizontal bending moment, akibat defleksi sumbu-Z, dan Tranverse bending moment, akibat defleksi sumbu-X.

1) Vertical Wave Bending Moment

Vertical bending moment merupakan penyebab beban akibat gelombang yang paling dominan terhadap struktur terapung. Berdasarkan GL Rules, perhitungan beban gelombang vertikal dapat digunakan persamaan sebagai berikut:

$M_{W V}=L^{2} \cdot B \cdot C_{0} \cdot C_{1} \cdot C_{L} \cdot C_{M}[k N m]$

dimana,

L : panjang kapal, $\mathrm{m}$

B : lebar kapal, $\mathrm{m}$

$\mathrm{C}_{0} \quad$ : koefisien gelombang

$\mathrm{C}_{1} \quad$ : kondisi hogging atau sagging

$\mathrm{C}_{1 \mathrm{H}} \quad: 0,19 \mathrm{Cb}$ kondisi hogging

$\mathrm{C}_{1 \mathrm{~S}} \quad:-0,11(\mathrm{Cb}+0,7)$ kondisi sagging

$\mathrm{Cb} \quad$ : block coefficient

$\mathrm{c}_{\mathrm{L}} \quad$ : koefisien panjang

$\mathrm{c}_{\mathrm{M}} \quad$ : faktor distribusi

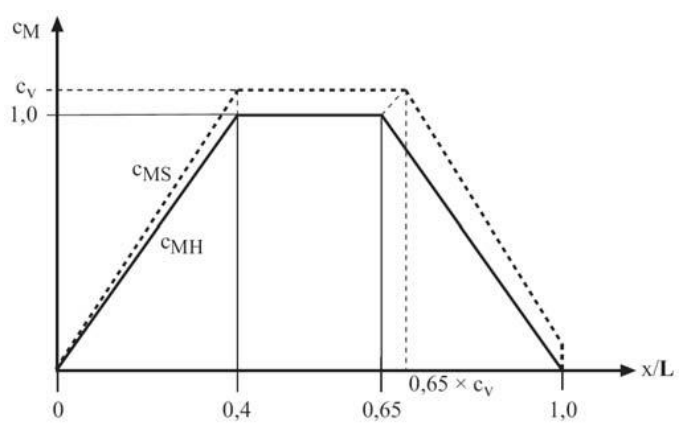

Gambar. 2. Distribution factor for $c M$ and influence factor $c v$

2) Vertical Wave Shear Force

Sebagaimana dengan vertical bending moment, vertical shear force juga merupakan penyebab utama tegangan geser pada struktur kapal. Berdasarkan GL Rules, 2005, perhitungan beban dapat digunakan persamaan sebagai berikut:

$Q_{W V}=L \cdot B \cdot C_{0} \cdot C_{Q} \cdot\left(C_{b}+0.7\right)[k N]$ dimana,

$\begin{array}{ll}\mathrm{L} & \text { : panjang kapal, } \mathrm{m} \\ \mathrm{B} & \text { : lebar kapal, } \mathrm{m} \\ \mathrm{c}_{0} & \text { : koefisien gelombang } \\ \mathrm{c}_{\mathrm{L}} & \text { : koefisien panjang } \\ \mathrm{Cb} & \text { : block coefficient } \\ \mathrm{C}_{\mathrm{Q}} & \text { : faktor distribusi }\end{array}$

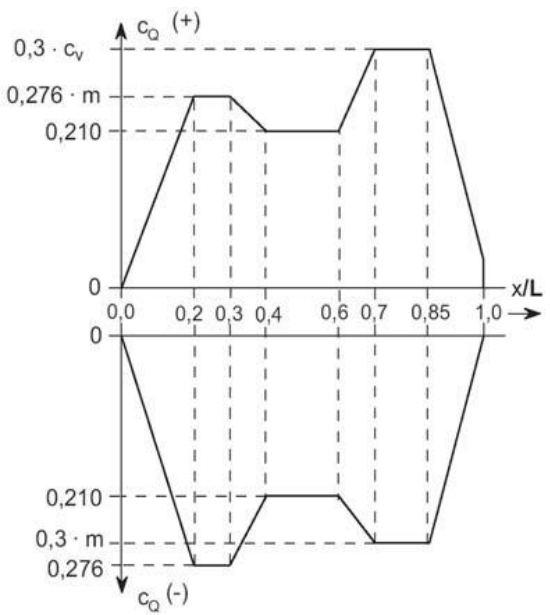

Gambar. 3. Faktor distribusi CQ [4]

\section{F. Kondisi Sagging dan Hogging}

Efek deformasi ship shaped structure akibat beban gelombang yang ditinjau denan mengibaratkan sebuah kapal bergerak pada gelombang regular dimana panjang gelombangnya sama dengan panjang kapal. Hal ini menyebabkan vertical bending moment. Jika hull diibaratkan sebagai beam, maka kondisi yang terjadi adalah:

1) Kondisi Hogging

Deformasi pada kapal berbentuk cembung. Pada kondisi ini, meskipun berat total seimbang dengan buoyancy, terdapat kelebihan buoyancy pada midship dan kelebihan berat pada bow dan stern. Situasi ini menyebabkan kecenderungan ujung kapal bergerak ke arah bawah dan pada bagian midship bergerak ke atas [5].
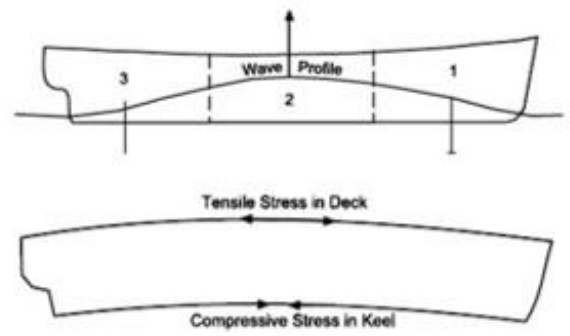

Gambar. 4. Kondisi hogging

2) Kondisi Sagging

Deformasi pada kapal berbentuk cekung. Terdapat kelebihan berat pada midship dan kelebihan bouyancy pada bow dan stern. Situasi ini menyebabkan kecenderungan ujung kapal bergerak ke arah atas dan pada bagian midship bergerak ke bawah [5]. 

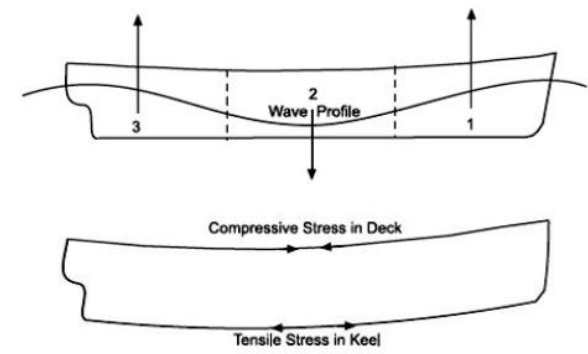

Gambar. 5. Kondisi sagging

Perhitungan Momen pada kondisi sagging dan hogging didasarkan pada perhitungan momen pada kondisi air tenang dengan menggunakan rumus sebagai berikut:

$\mathrm{MT}=\mathrm{Msw}+\mathrm{Mwv}$

$\mathrm{Mwv}=\mathrm{L}^{2} \cdot \mathrm{B} \cdot \mathrm{Co} \cdot \mathrm{C}_{1} \cdot \mathrm{C}_{\mathrm{L}} \cdot \mathrm{C}_{\mathrm{M}}$

dimana,

Msw $=$ Momen bending pada kondisi air tenang

$\mathrm{Co}=10.75-[(300-\mathrm{L}) / 100]^{1.5}$ untuk $90 \leq \mathrm{L} \leq 300 \mathrm{~m}$

$\mathrm{C}_{\mathrm{L}}=1$,

$\mathrm{C}_{1 \mathrm{~S}}=-0.11(\mathrm{Cb}+0.7)$

$\mathrm{C}_{1 \mathrm{H}}=0.19 \mathrm{Cb}$

$\mathrm{C}_{\mathrm{M}}=$ Distribution factor

$\mathrm{k} \mathrm{L}>90 \mathrm{~m}$

untuk kondisi sagging

untuk kondisi hogging

dengan,

1) Hogging Condition

$\mathrm{C}_{\mathrm{MH}}=2.5 \times \mathrm{x} / \mathrm{L}$

$\mathrm{C}_{\mathrm{MH}}=1 \quad$ untuk $0.4 \leq \mathrm{x} / \mathrm{L} \leq 0.65$

$\mathrm{C}_{\mathrm{MH}}=$ untuk $\mathrm{x} / \mathrm{L}>0.65$

2) Sagging Condition

$\mathrm{C}_{\mathrm{MS}}=\mathrm{cv} 2.5 \mathrm{x} / \mathrm{L}$

$\mathrm{C}_{\mathrm{MS}}=\mathrm{cv}$

$\mathrm{C}_{\mathrm{MS}}=\mathrm{cv}[(\mathrm{x} / \mathrm{L}-0.65 \mathrm{cv}) / 1-0.65 \mathrm{cv}]$

$\mathrm{C}_{\mathrm{MS}}=3 \sqrt{ }(\mathrm{Vo} / 1.4 \sqrt{\mathrm{L}}) \quad ; \mathrm{CV} \geq 1.0$

\section{G. Kondisi Sagging dan Hogging}

Tegangan pada kapal disebabkan oleh beban yang bekerja pada kapal sehingga terjadi bending moment. Besar tegangan rata-rata pada suatu bidang dapat didefinisikan sebagai intensitas gaya yang bekerja pada bidang tersebut. Tiap-tiap klasifikasi telah menentukan tegangan yang diijinkan pada kapal.

Menurut buku Dynamics of Marine Vehicles tegangan pada kapal ditampilkan dalam bentuk persamaan sebagai berikut:

$$
\sigma=\sqrt{\left(\frac{M_{V} z}{I_{V}}\right)^{2}+\left(\frac{M_{H} y}{I_{H}}\right)^{2}}
$$

dimana,

$\sigma \quad=$ tegangan pada kapal

$\mathrm{M}_{\mathrm{V}} \quad=$ momen lengkung searah vertikal

$\mathrm{M}_{\mathrm{H}} \quad=$ momen lengkung searah horisontal

$\mathrm{I}_{\mathrm{V}} \quad=$ momen inersia searah vertikal

$\mathrm{I}_{\mathrm{H}} \quad=$ momen inersia searah horisontal

Beberapa dari peraturan klasifikasi memiliki formula yang sama dalam menentukan tegangan ijin, misalnya Germanyscher's Lloyd, Biro Klasifikasi Indonesia, Lloyd's
Register. Adapun formula tegangan ijin yang dipakai adalah sebagai berikut:

$\sigma_{\mathrm{p}}=\mathrm{Cs} \cdot \sigma_{\mathrm{po}}$

dimana,

$\sigma_{\mathrm{p}} \quad=$ Tegangan memanjang kapal yang diijinkan

Cs $\quad=1.0$ untuk $0.3 \leq \mathrm{x} / \mathrm{L} \leq 0.7$

$\sigma_{\text {po }} \quad=175 / \mathrm{k}$ untuk $\mathrm{L} \geq 90 \mathrm{~m}$

\section{METODOLOGI PENELITIAN}

Penelitian ini secara keseluruhan dilakukan dengan analisis numerik. Hasil yang ingin didapatkan dari penelitian ini adalah besarnya tegangan yang terjadi akibat pengaruh beban gelombang pada struktur kapal perang tipe corvette. Metodologi penelitian dapat dilihat pada Gambar 6 .

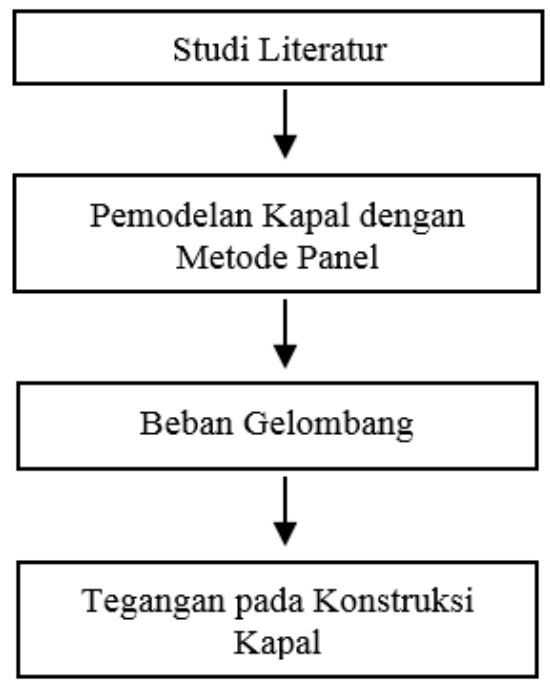

Gambar. 6. Diagram alir proses pengerjaan

Dalam proses penelitian ini, setelah data kapal telah didapatkan maka dilakukan proses pemodelan numerik dengan metode panel. Model kapal dibagi menjadi ribuan elemen atau panel. Kemudian elemen-elemen tersebut diintegrasi untuk mendapatkan respon akibat gelombang.

Secara teori, RAO adalah rasio kuadrat antara amplitudo gerakan kapal terhadap amplitudo gelombang. Kerena kapal tidak pernah bergerak di gelombang regular, maka data gelombang irregular dibutuhkan. ITTC memberikan formula untuk perhitungan spektrum gelombang berdasarkan pada significant wave height. Berdasarkan data yang didapat, kapal akan beroperasi pada ketinggian gelombang antara 3-6 $\mathrm{m}$.

Perkalian antara RAO dan spektrum gelombang pada menghasilkan respon spektrum gerakan kapal pada kondisi gelombang irregular. Respon spektrum ini digunakan untuk menghitung beban gelombang pada kapal.

Setelah beban gelombang didapatkan maka dilakukan perhitungan tegangan yang terjadi akibat beban gelombang yang mengenai badan kapal dan selanjutnya dibandingkan dengan tegangan ijin dari GL Class. 


\section{ANALISIS DAN PEMBAHASAN}

Ukuran utama kapal yang dianalisis dapat dilihat pada Tabel 1. Gambar 4 menunjukkan proses pemodelan kapal dengan metode panel dengan jumlah panel sebanyak 5085 panel / elemen.

Tabel 1.

Data ukuran utama kapal

\begin{tabular}{ccc}
\hline \hline Item & Nilai & Unit \\
\hline Loa & 106,00 & $\mathrm{~m}$ \\
$\mathrm{~B}$ & 14,00 & $\mathrm{~m}$ \\
$\mathrm{~T}$ & 3,70 & $\mathrm{~m}$ \\
$\mathrm{H}$ & 8,75 & $\mathrm{~m}$ \\
Vs & 30 & knot \\
\hline \hline
\end{tabular}

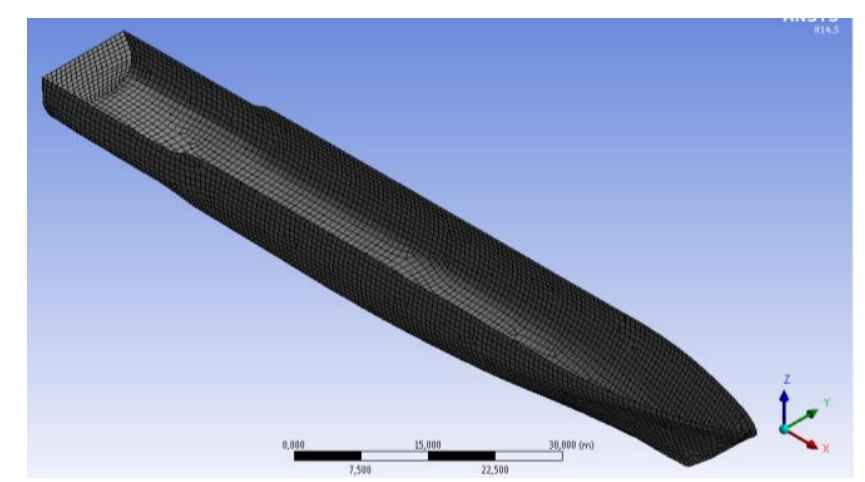

Gambar. 7. Model kapal perang

\section{A. Response Amplitude Operator (Shear Force / Bending Moment)}

Proses perhitungan response amplitude operator (shear force / bending moment) bertujuan untuk mengetahui seperti apa respon kapal ketika mendapatkan gaya lintang maupun momen lengkung pada kapal. Variasi pada perhitungan response amplitude operator ini adalah sudut hadap sebesar $90^{\circ}, 135^{\circ}$ dan $180^{\circ}$. Gaya lintang dan momen lengkung yang dititikberatkan pada penelitian ini adalah secara vertikal, oleh karena itu dilakukan perhitungan pada gerakan heave dan pitch.

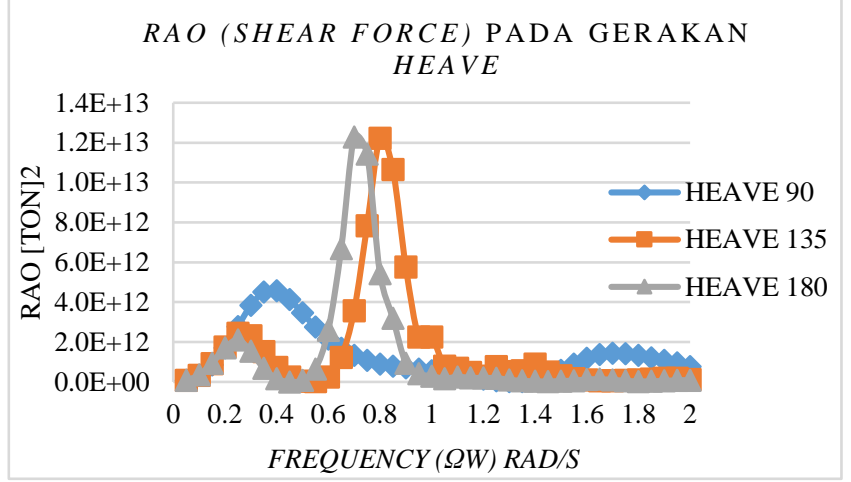

Gambar. 8. RAO (shear force) pada gerakan heave

Berdasarkan gambar 8. pada keadaan heave, dengan variasi sudut $90^{\circ}, 135^{\circ}$, dan $180^{\circ}$ dapat diketahui bahwa RAO (Shear Force) terbesar terjadi ketika kapal menadapat gelombang dengan sudut hadap $180^{\circ}$ pada frekuensi 0,7 dengan nilai $1,23 \mathrm{E}+12$ ton $^{2}$.

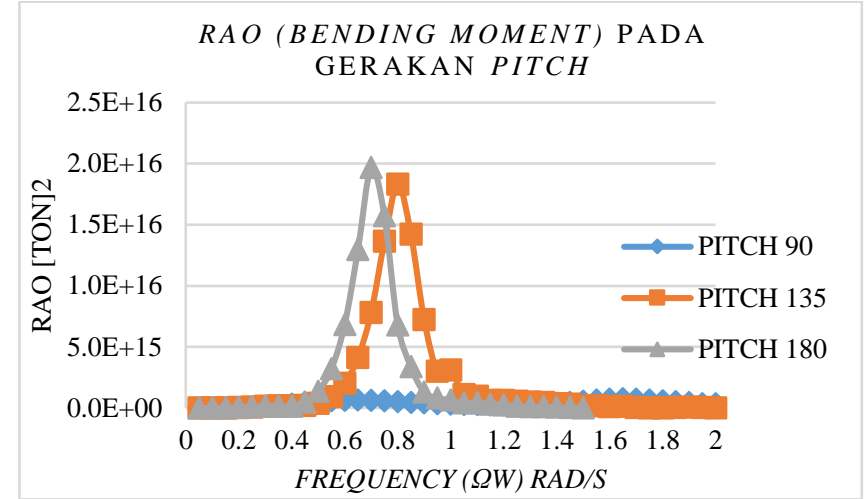

Gambar. 9. RAO (bending Moment) pada Gerakan Pitch

Berdasarkan gambar 9. pada keadaan pitch, dengan variasi sudut $90^{\circ}, 135^{\circ}$, dan $180^{\circ}$ dapat diketahui bahwa RAO (bending moment) terbesar terjadi ketika kapal menadapat gelombang dengan sudut hadap $180^{\circ}$ pada frekuensi 0,7 dengan nilai $1,97 \mathrm{E}+16$ ton $^{2}$.

\section{B. Hasil Spektrum Gelombang}

Dalam proses perhitungan, untuk mendapatkan gerakan kapal karena pengaruh gelombang, maka dilakukan perhitungan spektrum gelombang. Dalam pengerjaan penelitian ini menggunakan spektrum gelombang ITTC (International Towing Tank Conference).

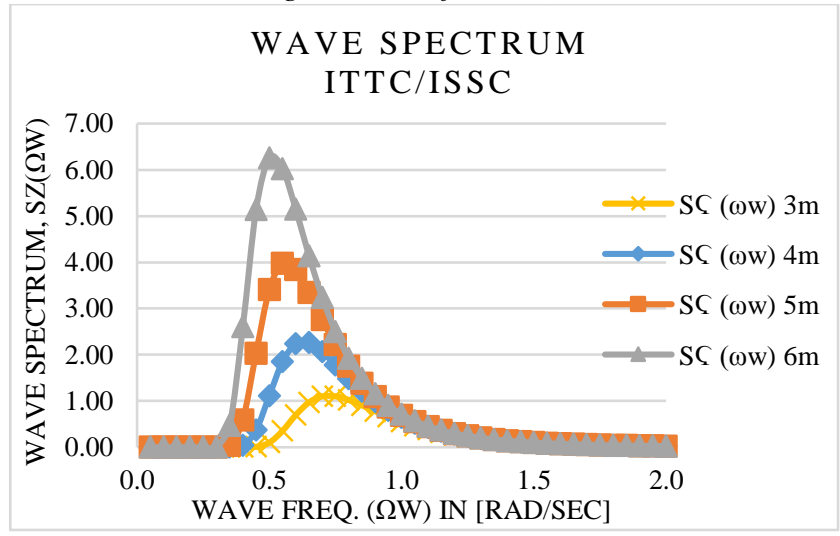

Gambar. 10. Spektrum Gelombang ITTC

Berdasarkan dari Gambar 10. dapat diketahui bahwa spektrum gelombang dengan tinggi gelombang signifikan yang berbeda yaitu mulai dari 3, 4, 5 dan $6 \mathrm{~m}$, maka menghasilkan spektrum gelombang yang berbeda-beda pula. Dimana berdasarkan grafik untuk spektrum gelombang terbesar adalah ketika tinggi gelombang signifikan $6 \mathrm{~m}$.

\section{Respon Spektrum Shear Force and Bending Moment}

Proses perhitungan respon spektrum ini bertujuan untuk mengetahui kondisi ekstrim kapal beroperasi, variasi dilakukan berdasarkan sudut hadap gelombang dan tinggi gelombang. Beban Gelombang terbesar cenderung diakibatkan oleh gerakan heaving dan pitching sehingga perlu didapatkan respon spektrum untuk setiap gerakan tersebut. Respone spectrume didapatkan dengan cara mengkalikan wave spectrum dengan RAO (shear force / bending moment). 


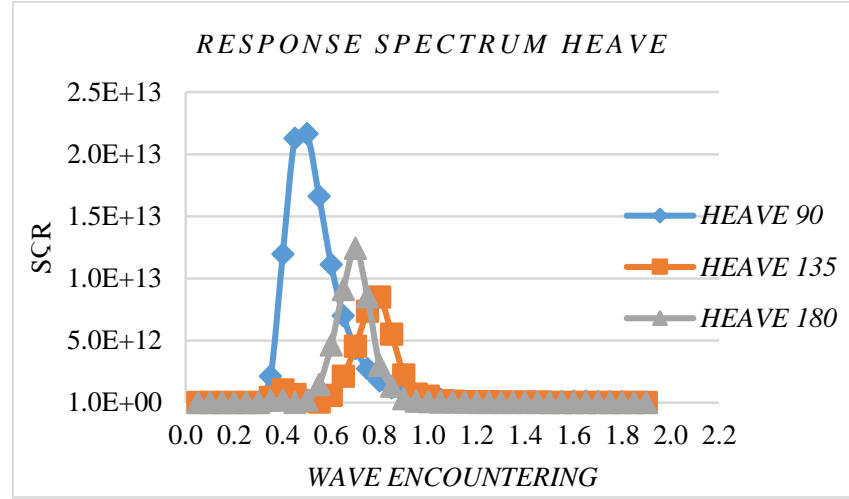

Gambar. 11. Response spektrum heave

Gambar 11 menunjukkan grafik respon spektrum gerakan heaving pada variasi sudut hadap. Respon terbesar terjadi pada sudut hadap $90^{\circ}$ dengan tinggi gelombang signifikan sebesar 6 m. Pada sudut hadap $135^{\circ}$, respon gerakan heaving kapal paling kecil.

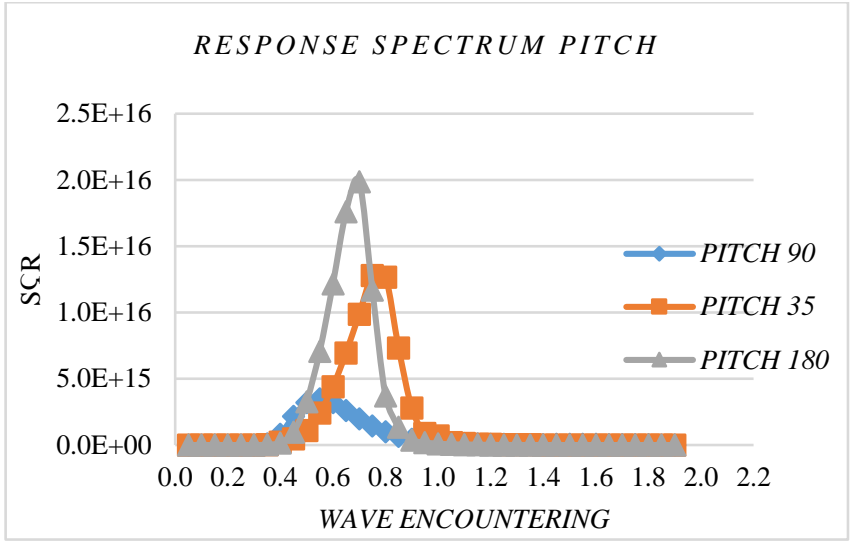

Gambar. 12. Response spetrum pitch

Gambar 12. menunjukkan grafik respon spektrum gerakan pitch pada variasi sudut hadap. Respon terbesar terjadi pada sudut hadap $180^{\circ}$ dengan tinggi gelomabng signifikan sebesar $6 \mathrm{~m}$. Pada sudut hadap $90^{\circ}$, respon gerakan pitch kapal paling kecil.

\section{Hasil Beban Gelombang}

Dengan diketahuinya respon gerakan kapal yang terjadi dengan variasi sudut heading $90^{\circ}, 135^{\circ}$ dan $180^{\circ}$ dan variasi tinggi gelombang signifikan 3, 4, 5 dan $6 \mathrm{~m}$ maka dapat dihitung besarnya beban gelombang berupa shear force dan bending moment yang terjadi sepanjang kapal.

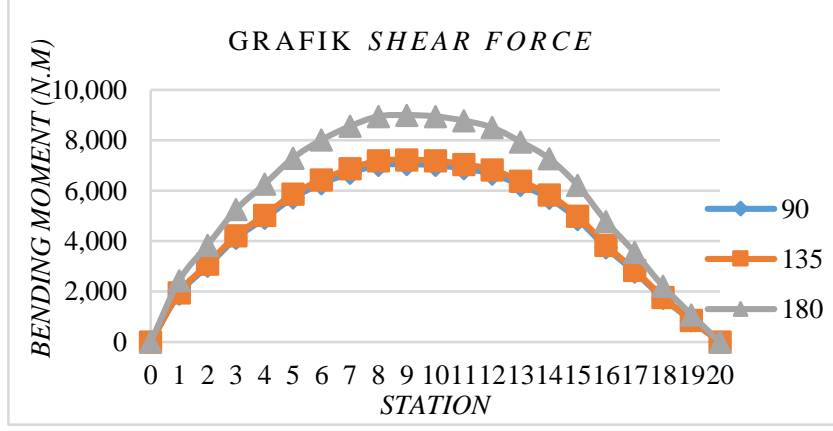

Gambar. 13. Distribusi beban gelombang pada gerakan heave
Gambar 13. menunjukkan grafik beban gelombang ketika gerakan heave pada variasi sudut hadap. Beban gelombang terbesar terjadi pada sudut hadap $180^{\circ}$ dengan tinggi gelombang signifikan sebesar $6 \mathrm{~m}$. Pada sudut hadap $90^{\circ}$, beban gelombang yang terjadi pada kapal paling kecil.

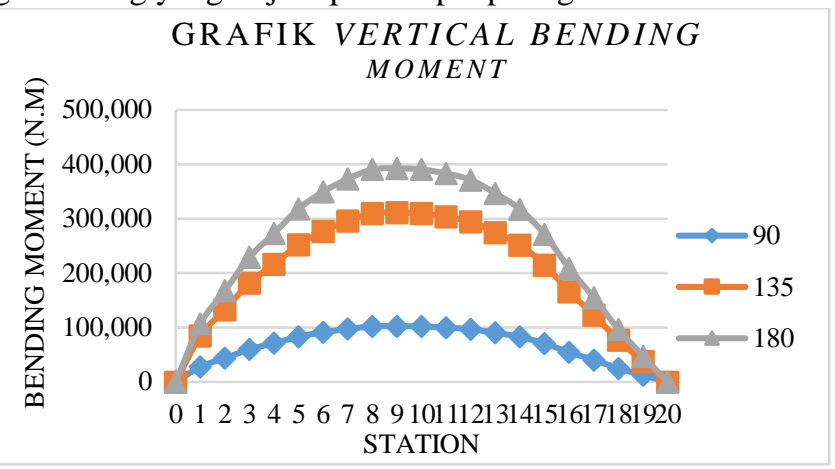

Gambar. 14. Distribusi beban gelombang pada gerakan pitch

Gambar 14. menunjukkan grafik beban gelombang ketika gerakan pitch pada variasi sudut hadap. Beban gelombang terbesar terjadi pada sudut hadap $180^{\circ}$ dengan tinggi gelombang signifikan sebesar $6 \mathrm{~m}$. Pada sudut hadap $90^{\circ}$, beban gelombang yang terjadi pada kapal paling kecil.

\section{E. Analisis Kekuatan Memanjang}

Tegangan yang terjadi akibat beban gelombang dengan variasi sudut hadap dan tinggi gelombang signifikan adalah sebagai berikut:

Tabel 2

Hasil tegangan pada kapal perang

\begin{tabular}{cccc}
\hline \hline \multirow{2}{*}{$\begin{array}{c}\text { Significant Wave } \\
\text { Height }(m)\end{array}$} & Wave Heading & \multicolumn{2}{c}{ Tegangan $\left(\mathrm{N} / \mathrm{mm}^{2}\right)$} \\
\cline { 3 - 4 } & $\left({ }^{\circ}\right)$ & Topdeck & Bottom \\
\hline \multirow{3}{*}{3} & 90 & 29,47 & 25,79 \\
& 135 & 118,52 & 103,71 \\
& 180 & 121,24 & 106,08 \\
& & & \\
4 & 90 & 40,67 & 35,58 \\
& 135 & 150,37 & 131,58 \\
& 180 & 172,37 & 150,83 \\
5 & 90 & & \\
& 135 & 51,08 & 44,69 \\
& 180 & 170,43 & 149,12 \\
& 90 & 207,51 & 181,58 \\
& 135 & 60,50 & 52,94 \\
6 & 180 & 183,84 & 160,86 \\
& & 231,89 & 202,90 \\
\hline \hline
\end{tabular}

Dengan tegangan ijin sebesar $243 \mathrm{~N} / \mathrm{mm}^{2}$, maka tegangan pada kapal telah memenuhi tegangan ijin dari GL Rules.

\section{KESIMPULAN DAN SARAN}

\section{A. Kesimpulan}

1) Beban gelombang terbesar pada kapal perang tipe corvette terjadi pada tinggi gelombang signifikan sebesar $6 \mathrm{~m}$. Dengan besar shear force maksimal pada gerakan heave dengan sudut hadap $90^{\circ}$ sebesar $9001,84 \mathrm{kN}$ dan bending moment maksimal pada gerakan pitch dengan sudut hadap $180^{0}$ sebesar $392.816,82 \mathrm{kNm}$.

2) Tegangan global yang terjadi dipengaruhi oleh besarnya tinggi gelombang signifikan dan variasi wave heading. 
Semakin besarnya tinggi gelombang signifikan maka tegangan global juga semakin besar, selain itu dengan wave heading yang semakin besar mulai dari $90^{\circ}, 135^{\circ}$, dan $180^{\circ}$ maka tegangan juga semakin besar. Dimana besar tegangan yang terjadi pada setiap tinggi gelombang signifikan 3, 4, 5 dan $6 \mathrm{~m}$ berturut-turut adalah 121,24 $\mathrm{N} / \mathrm{mm}^{2}, 172,37 \mathrm{~N} / \mathrm{mm}^{2}, 207,51 \mathrm{~N} / \mathrm{mm}^{2}$ dan $231,89 \mathrm{~N} / \mathrm{mm}^{2}$.

3) Tegangan maksimal pada frame 88 (midship section) tersebut terjadi ketika mendapat gelombang dengan tinggi gelombang signifikan $6 \mathrm{~m}$ dan wave heading $180^{\circ}$ yang terletak pada bagian top deck sebesar $208.08 \mathrm{~N} / \mathrm{mm}^{2}$. Dengan adanya tegangan ijin menurut GL-Rules sebesar $243.4 \mathrm{~N} / \mathrm{mm}^{2}$, maka dapat disimpulkan bahwa tegangan telah memenuhi pesyaratan dari tegangan ijin kapal.

\section{B. Saran}

Dalam penelitian ini masih ada kekurangan - kekurangan yang terjadi, oleh karena masih banyaknya pokok bahasan yang akan diteliti dan dikembangkan lagi, selain itu untuk saran pada penelitian selanjutnya, adalah sebagai berikut:

1) Dalam proses pengerjaan penelitian ini, gerakan kapal masih menggunakan gerakan kapal yang bersifat individu. Disarankan dalam penelitian selanjutnya menggunakan gerakan kapal yang saling berpasangan atau dikombinasikan antar gerakan tersebut untuk mendapatkan hasil yang lebih akurat.

2) Untuk penelitian selanjutnya diharapkan mengkombinasikan secara langsung dalam 1 perangkat lunak mengenai interaksi gelombang dengan struktur kapal.

\section{DAFTAR PUSTAKA}

[1] "Perisai Serangan Rudal Anti Kapal di Korvet Sigma Class TNI AL," 2015. [Online]. Available: http://www.indomiliter.com.

[2] "Informasi Meteorologi Maritim Gelombang Tinggi di Indonesia," 17 September 2015. [Online]. Available: http://www.bmkg.go.id.

[3] R. Bhattacharyya, Dynamic of Marine Vehicle, U.S. Naval Academy, Annapolis: Marryland, 1978.

[4] G. Lloyd, Rules of Classification and Construction Ship Technology, Jerman: Germanischer Lloyd, 2012.

[5] Barras, Ship Stability for Master and Mates, Oxford: Elseiver, 1999. 